\title{
Developing Crop-Specific Irrigation Management Strategies Considering Effects of Drought on Carbon Metabolism in Plants
}

\author{
Silvia Aparecida Martim¹, Arnoldo Rocha Façanha² \\ and Ricardo Enrique Bressan-Smith ${ }^{3}$ \\ Instituto de Biologia, Departamento de Ciências Fisiológicas, \\ Universidade Federal Rural do Rio de Janeiro \\ ${ }^{2}$ Centro de Biociência e Biotecnologia, Laboratório de Biologia Celular e Tecidual, \\ Universidade Estadual do Norte Fluminense - Darcy Ribeiro \\ ${ }^{3}$ Centro de Ciências e Tecnologia Agropecuária, Laboratório de Fisiologia Vegetal, \\ Universidade Estadual do Norte Fluminense - Darcy Ribeiro \\ Brazil
}

\section{Introduction}

Development of appropriate irrigation managements in order to produce crops of high quality without water waste is a relevant theme worldwide in the face of the global environmental change and the related perspectives for a future increment in dryness (IPCC, 2001). Drought stress imposes adverse effects on plant yield and productivity affecting mainly leaf and root growth, stomatal conductance, photosynthetic rate and biomass gain (Blum, 1998). Based on studies carried in the last decade, it is clear that plants perceive and respond quickly to minima modifications in water status by means of a series of cellular, physiological and molecular events developing in a parallel feature (Chaves et al., 2009). The duration, intensity and rate of evolution of forced drought are responsible to modulate the various levels of response.

All living organisms depend directly or indirectly from the energy of photosynthesis, the only process that can absorb the energy from the sun to oxidize water, release oxygen and to reduce carbon dioxide forming carbohydrate. On that basis, how decreasing cellular water content affects the photosynthetic process is an interesting issue for present and future debates (Krieg, 1983; Chaves, 1991; Lawlor and Cornic, 2002; Flexas and Medrano, 2002; Chaves et al, 2009). Photosynthesis consists of a set of integrated reactions submitted to a range of conditions under environmental and genetic control. Under field conditions, it is accepted that the decrease in photosynthesis in response to moderate water stress in soil and/or atmosphere is firstly due to stomata closure (Chaves et al., 2002, 2003). However, the extent and the nature of the restriction of carbon assimilation in leaves under water stress occur, mainly due to stomata or non-stomata limitations, is still in debate (Tzara et al. 1999; Cornic, 2000, Lawlor and Cornic, 2002; Flexas et al., 2004).

Changes in plant growth elicited by low water availability have also been associated to modulations on the balance between photosynthesis and respiration. These processes are 
intimately related (Bartoli et al., 2005; Flexas et al., 2006; Martim et al 2009). In general, from the total carbon incorporated in carbohydrate by photosynthesis, more than $50 \%$ is spent in respiratory rates; nevertheless, this relationship may alter under drought conditions. Respiration is an essential metabolic process that generates not only Adenosine TriPhosphate (ATP) but several carbon skeletons - metabolites that are used in many synthetic processes essential for growth and maintenance of the cell homeostasis, including under stress conditions (MacCabe et al., 2000; Bartoli et al., 2000). Remarkably, mitochondria are involved in several metabolic process concerned in cell adaptation to abiotic stress, like photorespiratory cycle (Kramer, 1995), proline metabolism which accumulates under hyperosmotic stress (Kiousue et al., 1996), programmed cellular death (Rhoads et al., 2006), themselves and the cell defense from a excess Reactive Oxygen Species (ROS) particularly under salinity and drought (Alsher et al., 1997).

Other implications to plant development in response to drought is the altered partitioning of carbon between the leaf and others organs (Chaves, 1991). The amount of carbon available for storage, maintenance and translocation is determined by key regulatory process in source leaves. Under water deficit, there is a strong reduction in levels of inactive osmotically solutes (starch) and increase in active osmotically solutes (soluble sugars) and as a consequence the osmotic potential decreases, contributing to the maintenance of leaf water status (Pelleschi et al., 1997; Pinheiro et al., 2001; Yang et al., 2001). Sucrose plays a crucial role in plant growth and development not only as a key molecule in energy transduction and storage, but also because there is increasing evidence that sucrose or several metabolites derived from it may function as regulators of cellular metabolism (Smeekens and Rook, 1997). Moreover, the sugars play a substantial role during plant growth and development under abiotic stress, especially drought. Like a hormone, sugars can act as primary messengers and regulate signals that control the expression of several genes involved in sugar metabolism. Nevertheless, the use of sucrose as carbon source and energy depends on their hydrolysis into hexoses catalyzed by sucrose synthase or invertase. Invertase (EC 3.2.1.26, $\AA$-fructofuranosidase) is a hydrolase present in diverse isoforms with different biochemical properties and subcellular localization (Sturm, 1996). The invertases have a key important role in several cellular processes like phloem loading/unloading, defense response to abiotic and biotic stresses and cellular turgor recover (Sturm and Tang, 1999).

Agriculture represents $70 \%$ of freshwater expenditure worldwide, and this percentage rises above $90 \%$ in arid countries (WRI, 2005). Therefore, the water availability for irrigation is scarce in many areas due to aridity increment in the world and competition for water by households, agriculture and industry (IPCC, 2007). Consequently, there are urgent needs to expand the use of irrigation management that improves high yield, quality and water use efficiency (WUE). Two techniques are widely used and investigated for this proposal: Deficit irrigation (DI) and Partial root-zone drying (PRD). Deficit irrigation is a strategy in which water is applied during drought-sensitive growth stages and water restraint is employed to drought-tolerant phenological stages, commonly the vegetative stages and the terminal ripening period. Partial root-zone drying (PRD) is innovation deficit irrigation (DI), which the water is provided only to one side of the root system leaving the other part to dry a certain water potential of the soil before rewetting by shifting irrigation to the dry side. As a consequence, the abscisic acid produced by roots in the dehydrating side is the chemical signal sent to the shoots and leaves via xylem that invariably reduces the stomatal conductance, transpiration and vegetative growth. At the same time, roots of the watered 
side maintain a favorable plant water status (Dry and Loveys, 1999; Dry et al., 2000, 2001; Chaves and Oliveira, 2004).

This chapter will focus the changes occurred in carbon metabolism from carbohydrate production (photosynthesis) until consumption (respiration) including the partitioning (sugar metabolism), in response to drought. Such a information will be discussed as a new approach to develop crop-specific irrigation managements.

\section{Production and consumption of carbon under low water availability}

From all processes that contribute to plant development, cell growth and photosynthesis are the firstly affected by drought. When the availability of water in the soil is scarce or vapor deficit pressure of the atmosphere is high, plants firstly respond by decreasing the stomatic aperture. As the main role of stomata is to perform gas exchange, this strategy has two consequences, prevent the water loss and limit $\mathrm{CO}_{2}$ diffusion. Consequently, this might cause the reduction of the photosynthetic rates in drought conditions. Nevertheless, the extension and the nature of the diminished carbon assimilation in water stressed leaves are due to stomatic or non-stomatic limitations, a theme still under discussion (Tzara et al., 1999; Cornic, 2000; Lawlor and Cornic, 2002; Flexas et al., 2004).

Photosynthetic rate is gradually diminished with progressive reduction in relative water content (RWC). The complexity of photosynthesis is based on the activity of Rubisco (Ribulose 1,5 Biphosphate Carboxylase/Oxygenase) per unit leaf, the rate of RuBP (Ribulose Bisphosphate) resynthesis (hence on capture of photosynthetically active radiation (PAR)) and on the $\mathrm{CO}_{2}$ supply, given by stomatic conductance $\left(\mathrm{g}_{\mathrm{s}}\right)$ and the ambient $\mathrm{CO}_{2}$ concentration $\left(\mathrm{C}_{\mathrm{a}}\right)$.

The $\mathrm{CO}_{2}$ availability to the chloroplast is intrinsically dependent of the ambient $\mathrm{CO}_{2}$ concentration and the pathway for diffusion between air and carboxilation site, mainly stomatic conductance in gas phase $\left(\mathrm{g}_{\mathrm{s}}\right)$ and mesophilic conductance $\left(\mathrm{g}_{\mathrm{m}}\right)$ in liquid phase. In hydrated leaves and a saturated environment with $\mathrm{CO}_{2}$ and light the maximum rate of photosynthesis is denominated potential photosynthesis (Apot) (Lawlor and Cornic, 2002). Moreover, when relative water content lowering, to obtain the Apot is necessary Cc to saturated Rubisco and sufficient $\mathrm{Ca}$ to suppress the barriers imposed by stomatic and mesophilic conductances. In the first moment, when RWC decreased and the photosynthetic rate diminished, a high $\mathrm{CO}_{2}$ concentration ( $\left\{50\right.$ a $\left.150 \mathrm{~mL} \mathrm{~L}^{-1}\right\}$ de 5 a $\left.15 \%\right)$ can restore $\mathrm{A}$ to values near Apot, and consequently, the $\mathrm{A}$ is unaffected. Afterwards, the decreased photosynthesis cannot be restored by high $\mathrm{CO}_{2}$ concentrations showing that Apot is impaired by metabolic factors. Parallel to this, photosynthesis fall gradually as RWC decreases showing that Apot is progressively inhibited and the effects of stomatic conductance are diminished. This response built from photosynthetic rate $\mathrm{x}$ internal concentration of $\mathrm{CO}_{2}$ are termed response type I and Type II (Lawlor and Cornic, 2002).

Some species such Rhamnus alatemus, Rhamnus ludovici-salvatoris, Nicotiana sylvestris, Phaseolus vulgaris and Vitis vinifera have their photosynthetic rate mainly limited by stomatic conductance at the beginning of drought development. As drought severity evolves, activity of Rubisco is impaired and the levels of RuBP diminished, consisting as the main limiting factors for photosynthesis (Bota et al., 2004). In another way, plants like grasses show the carbon assimilation and quantic efficiency of photosystem II $(\sqrt{ }$ PSII $)$ decreased quickly with RWC decline (Ghannoum et al., 2003). For these plants, the application of 2500

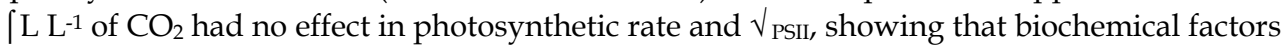


are limiting the photosynthetic process. In sunflower leaves, inhibited synthesis of RuBP caused by lower ATP content and not the $\mathrm{CO}_{2}$ diffusion is the limiting factor to the photosynthesis (Tzara et al., 1999). Linear photosynthetic electron transfer consisting of Photosystem II (PSII) and and Photosystem I (PSI), both capable to convert light energy into chemical energy as ATP and reducing power NADPH, whereas PSI cyclic electron transfer (CET) is merely involved in ATP synthesis. ATP and NADPH from thylakoid linear electron transport are employed to chloroplast $\mathrm{CO}_{2}$ or $\mathrm{O}_{2}$ reduction. The electron flow in photosynthetic membranes is highly regulated and strongly dependent from substrate availability and redox level of the transfer cycle.

A little reduction in soil water content caused different degree of inhibition in photosynthetic rate and increase of non-photochemical quenching of chlorophyll a fluorescence in grapevine (Flexas et al., 1999). Under moderate drought the correlation between $\mathrm{CO}_{2}$ assimilation and electron transfer was maintained, however under severe drought a strong inhibition of photosynthesis broke the mentioned correlation. The degree to which water stress impair the linear electron transport on thylakoid and the partitioning of electrons between produced in photosystem II (PSII) and consumed by acceptors depend on leaf water potential. In sunflower leaves, the chloroplast activity begins to reduce at the same leaf water potential that causes the stomatal closure and the electron transport begins to limit photosynthesis at leaf water potential below -1.1 MPa (Keck and Boyer, 1974). To investigate the linear photosynthetic electron transfer under drought conditions, it is necessary to consider two issues: the photosynthetic apparatus resistance and the substrate availability to chloroplast reactions. The carbon reduction by photosynthetic cycle is so far the main consumption of the electrons from water oxidation. So, when carbon assimilation decreases in consequence of a lower RWC, there is an increase in reactive oxygen species (ROS) due to strong reduction in LPET and consequently increase the electron transfer to oxygen. In the absence of alternative cycles to use the electrons this is extremely damaging to the cells. When the photosynthesis decreases in response to lowering RWC, the most important way to use the electrons is the photorespiration, dark respiration and Mehler reactions (Cornic and Briantais, 1991). In general, a large portion of the total flow of electron is used by photorespiration that plays a key role in redox regulation until LPTE-reducing by low carbon assimilation (Haupt-Herting and Fock, 2000, 2002).

It is clear that drought induces several alterations in photosynthetic rate, often arisen as part of an overall response to desiccation which involve specific gene expression. In some cases, these alterations are consequence to self-resistant of the photosynthetic apparatus. The decrease in $\mathrm{Ci}$ caused metabolic change which limits photosynthesis reversibly being the photosynthetic apparatus damaged with advancement of drought (Cornic, 2000). However, under filed conditions is usually accepted that the decrease in photosynthetic rate in response to moderate water stress (RWC 70-75\%) is in first instance due to closed stomata (Chaves et al., 2002, 2003). In general reductions in transpiratory rate are associated with the stomatal aperture occurred at low water potential. In this condition the water use efficiency (WUE) instantly defined as the ratio $\mathrm{A}_{\mathrm{N}} / \mathrm{E}$ can be enhanced to maintain cellular metabolism and plant survival. This event can be mostly observed in plants drought tolerant like grapevine (Pou et al., 2008; Martim et al., 2009), alfafa (Erice et al., 2011) and droughttolerant maize (Hund et al., 2009). Mediterranean plants with different growth pattern showed increase in leaf WUE with the initial decrease of water availability, but WUE decreased with lower water availability (Medrano et al., 2009). According to the authors, this pattern is explained by the relative changes of photosynthesis and stomatal conductance 
as soil water deficit progress. This physiological process gives the plants the strategy of optimize carbon assimilation and minimize water losses related to decrease in $\mathrm{g}_{\mathrm{s}}$ which only causes a modest photosynthetic reduction. The later decrease in WUE of plants can be explained by metabolic impairment of the photosynthetic apparatus.

Focusing on concept of water use efficiency to the amount of water transpired relative to the amount applied with emphasis on soil factors that influence this ratio, any factor that restricts the root system reduces WUE. However, it is hardly known whether transpiration or WUE is mostly affected by a long period of soil compaction. The degree of consumption and loss of water is directly related with plant productivity like observed to wheat and maize where soil compaction reduced grain yields by reducing soil water storage and/or crop WUE (Radford et al 2001). Soil compaction involves an increment in soil bulk density and connected with this are increment in soil strength and decrease in air permeability and hydraulic conductivity. In modern agriculture, the majority of soil compaction is caused by vehicular traffic (Flower and Lal, 1998). Soil compaction originating from anthropogenic or natural causes exerts an enormous impact on the establishment, growth and yield of crops in tropical regions. The capacity of intake water via roots located in deep wet soil layers is a key factor determining transpiration under soil dried conditions. Soil compaction affects root growth by increase mechanical resistance, lowering water availability and oxygen diffusion or by restricting nutrient supply. In regions where the soil resistance to penetrometer exceeding approximately $0.5 \mathrm{MPa}$, roots experiences great difficult to penetrate (Young et al. 1997) and they stop growing when soil resistance reaches $3.6 \mathrm{MPa}$ (Masle, 1999). In contact with compact soil, root deepening is delayed and roots tend to have a clumped spatial arrangement causing water stress even in wet soil, due to an increase in resistance to the soil-root water flux. However, the extent to which WUE is diminished when root system employed their energy exploring complex channels rather than more direct paths toward water and nutrients is still unclear.

In limited availability of water, plant productivity is determined by amount of water available as well as water use efficiency. In agriculture, absorption and transpiration by the crop canopy determine the flow of water and $\mathrm{CO}_{2}$ and therefore canopy photosynthetic water productivity and biomass water productivity. Shifting the focus from leaf to canopy there is an additional feature that should be considered because the approach is on a land area basis instead of leaf area basis. The radiation capture by a crop is intrinsically dependent of leaf area, generally evaluated by the leaf area index (LAI) on the arrangement of the leaves within the canopy as well as on the angle and intensity of incident radiation. Besides the solar radiation, plant density and the stage of vegetative growth determinate radiation interception. Moreover, of the total captured solar radiation just the portion that is photosynthetically active (PAR) is effective in $\mathrm{CO}_{2}$ assimilation, while the whole spectrum is used for transpiration. At the canopy level the $\mathrm{CO}_{2}$ assimilation of many crops usually doesn't reach light saturation meaning that a linear response to irradiance is observed (Lowerse, 1980; Asseng and Hsiao, 2000). Then, any change in the quantity of radiation captured by canopy would affect at the same way $\mathrm{CO}_{2}$ assimilation and transpiration. Nevertheless, at the canopy level, the $\mathrm{CO}_{2}$ and water vapor share the transport pathway and energy source. A difference in that sensible heat flux can either add or remove energy for transpiration from the canopy independent of radiation. Therefore, the sharing of radiative energy source is a critical and often dominant factor in connecting $\mathrm{CO}_{2}$ assimilation and transpiration rates at the canopy level. 
When cultivated under non-stress conditions the maximum yield is defined as yield potential. WUE is mainly discussed in terms of plant production rather than gas exchange. At this framework, yield under drought conditions can be determined by genetic factors controlling yield potential and/or drought resistance and/or WUE. Photosynthesis is the primordial process to plant because the carbon compounds synthesize with input of energy from sunlight will be employed in several metabolic reactions. So, under stress conditions there should be a rearrangement at the cellular, molecular, biochemistry and physiological level to maintain the integrity of the photosynthetic apparatus. Photosynthetic apparatus is considered resistant to drought and its structure is not affected by inhibition of photosynthesis imposed by reductions in stomatal conductance which provide quickly responses of leaves to changes in environment water status. There is a number of studies showing the resistance of photosystem II (PSII) to soil desiccation (Abreu and Munné-Bosch, 2008; Munné-Bosch et al. 2009; Chernyad'ev, 2009; Georgieva et al. 2010; Ibáñez et al. 2010; Hura et al. 2011). This fact can be evidenced by the ability to recover of photosynthetic rate measured after re-irrigation of plants exposed to water scarcity. The dehydration of Haberlea plants leading the inhibition of quantum efficiency of PSII which was due to decreased efficiency of both excitation capture by open PSII reaction centres and, mainly, of photochemical quenching. In addition the $\mathrm{CO}_{2}$ assimilation decreased sharply as a result of dehydration featuring no net assimilation seven days after dryness. But, seven days after rehydration of stressed plants the $\mathrm{CO}_{2}$ assimilation was comparable to the irrigated plants (Georgieva et al. 2010). Table 1 shows that in stressed plants of Cabernet Sauvignon photosynthetic rate $\left(\mathrm{A}_{\mathrm{N}}\right)$, stomatal conductance $\left(\mathrm{g}_{\mathrm{s}}\right)$, transpiratory rate $(\mathrm{E})$ and internal carbon concentration $\left(\mathrm{C}_{\mathrm{i}}\right)$ declined with drought progress reaching the lowest values at the severe stress. However, gas exchange and leaf water potential measured 48 hours after rehydration of stressed plants presented recovery potential which $A_{N}$ and $C_{i}$ showed values very close to control.

\begin{tabular}{|c|c|c|c|c|c|c|}
\hline Treatment & $\begin{array}{c}\mathrm{A}_{\mathrm{N}} \\
\left(\mu \mathrm{mol} \mathrm{CO} \mathrm{C}_{2} \mathrm{~m}^{-1}\right)\end{array}$ & 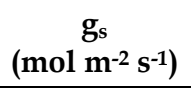 & $\begin{array}{c}E \\
\left(\mathrm{mmol} \mathrm{m}^{-2} \mathrm{~s}^{-1}\right)\end{array}$ & $\begin{array}{c}\mathrm{C}_{\mathrm{i}} \\
(\mathrm{ppm})\end{array}$ & WUE & $\mathbf{A}_{N} / C_{i}$ \\
\hline Irrigated & 11.9 & 0.8 & 14 & 304 & 0.8 & 0.04 \\
\hline Mild-stress & 8.8 & 0.1 & 5.4 & 234 & 1.6 & 0.04 \\
\hline Severe-stress & 1.8 & 0.01 & 194 & 0.6 & 3.3 & 0.01 \\
\hline Re-irrigation & 11.1 & 0.3 & 11.2 & 294 & 1.0 & 0.04 \\
\hline
\end{tabular}

Table 1. Photosynthetic rate $\left(\mathrm{A}_{\mathrm{N}}\right)$, stomatal conductance $\left(\mathrm{g}_{\mathrm{s}}\right)$, transpiration $(\mathrm{E})$, internal $\mathrm{CO}_{2}$ concentration $\left(\mathrm{C}_{\mathrm{i}}\right)$, water use efficiency (WUE) and carboxylation efficiency (AN/Ci) measured in Cabernet plants under different water availability.

Changes in plant growth elicited by low water availability have also been related to modulations on the balance between photosynthesis and respiration. These processes are intimately related, and in the last decade has been increasing interest in the interaction between them (Bartoli et al., 2005; Flexas et al., 2006; Martim et al 2009). Photosynthesis is a complex process and to achieve optimal rates must occur the interaction of chloroplasts with cytosol and other organelles such a mitochondria. Of the total carbon assimilated in photosynthesis, commonly more than $50 \%$ is lost in respiration required for plant growth 
and maintenance; however, this relationship may change under drought. For instance, while the photosynthetic rate may decrease up to $100 \%$ becoming totally damaged in severe drought conditions, the respiration rate may either increase (Bartoli et al., 2005; Martim et al., 2009) or decrease (Huang and Fu, 2000; Galmes et al., 2007) but may never become fully damaged. Respiration is an essential metabolic process that generates not only ATP but several other metabolites that are used in many synthetic processes essential for growth and maintenance of the cell homeostasis, including under stress conditions (MacCabe et al., 2000; Bartoli et al., 2000).

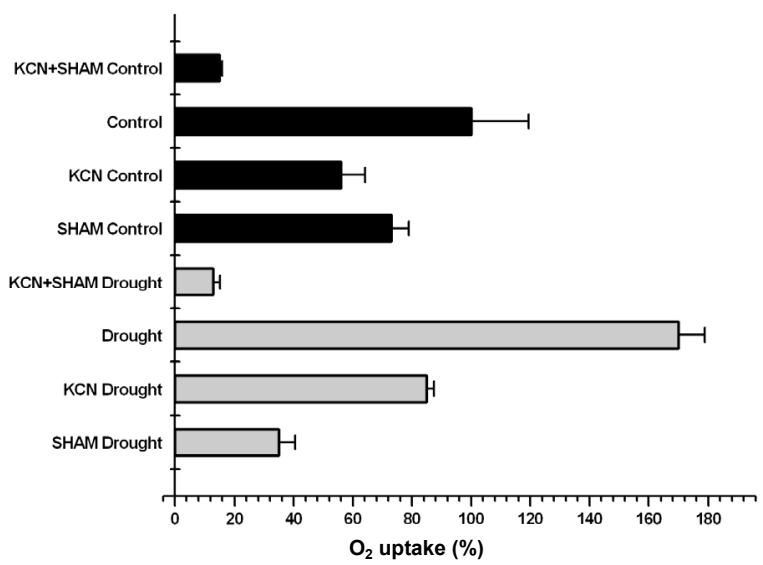

Fig. 1. Respiratory activity of Cabernet Sauvignon leaves. Oxygen consumption was monitored in young leaves of plants either Irrigated (control) or expressed to drought treatment (D) and following the addition of $1 \mathrm{mM} \mathrm{KCN}, 10 \mathrm{mM}$ SHAM or both.

A special feature of plant cell respiration is the presence of an alternative pathway which drains electrons from the ubiquinone pool without involvement of the cytochrome oxidase (COX) (Brownleader et al., 1997). The mitochondrial alternative oxidase (AOX) apparently reduces molecular oxygen to water in a single four-electron transfer step (Day et al., 1991; Moore and Siedow, 1991). This alternative pathway is nonphosphorylating, resistant to cyanide and antimicine and inhibited by salicilhydroxamic acid (SHAM) and n-propyl gallate (nPG) (Schonbaum et al., 1971; Siedow and Grivin, 1980). Studies focusing respiration rate in response to drought is particularly lower than those about photosynthetic rate. In general, the respiratory pathway decreases during a drought period due to decrease photosynthetic activity and growth. However, this behavior is species dependent but the respiration can increase particularly under severe stress (Flexas et al., 2005; Ghasghaie et al., 2001). After experiencing a drought period, plants may require a increasing in respiratory rate (Kirschbaum, 1987). In wheat leaves Bartoli et al (2005) observed that respiratory rate increased $41 \%$ when RWC decreased to $75 \%$ in relation to $97.2 \%$ in hydrated leaves, this respiratory increase was due to alternative oxidase that doubled the oxygen consumption. Data of our previous research showed that in Vitis vinifera L. cv. Cabernet Sauvignon, the respiratory rate of leaves increased around $74 \% 12$ days after water suspension. This increase was due mostly to an enhancement of the alternative pathway activity as observed in leaves treated with $1 \mathrm{mM}$ potassium cyanide $(\mathrm{KCN})$ an effective COX inhibitor (Table 2). 
At the same time, stomatal conductance, assimilation rate and internal $\mathrm{CO}_{2}$ concentration in leaves of stressed plants decreased $98 \%, 83 \%$, and $21 \%$, respectively, along with the progress of the water deficit treatment. So, it is worth emphasizing that photosynthesis also requires interactions of chloroplasts with the mitochondria to attain optimal rates (Hoefnagel et al. 1998; Padmasree and Raghavendra, 1999; Dutilleul et al. 2003; Noctor et al. 2004; NunesNesi et al. 2008). In this context, it is likely that the stimulation of the AOX pathway observed in grapevine might represent an important response protecting the photosynthetic machinery under drought conditions.

There are several studies showing that the alternative oxidase increase in plants under some environmental conditions (Padmasree and Raghavendra, 1999; Bartoli et al., 2005; Yoshida et al., 2007; Feng et al., 2008). The increment in alternative oxidase under stress conditions represent a important response to protection of the photosynthetic apparatus against the harmful effects of energy excess. In despite this, the electron partitioning between COX and AOX is modified at the same values of stomatic conductance limiting photosynthesis. At the saturating photosynthetic photon flux density (PPFD) AOX functioning keeps the photosynthetic electron transport chain more oxidized in Broad beans plants, where the AOX inhibition decreased the $\mathrm{O}_{2}$ evolution rates and quantum efficiency of PSII $(\phi I I)$ (Yoshida et al. 2006). The authors observed that AOX inhibition by SHAM induced a clear decreased in photochemical quenching $(\mathrm{qP})$ and AOX inhibition by $\mathrm{nPG}$ lead the prompt increase in non-photochemical quenching $(\mathrm{qN})$ after onset of irradiation. Moreover, AOX inhibition diminished the $\mathrm{O}_{2}$ evolution and $\phi I I$ even at low PPFD and cause imbalance of operating efficiencies between two photosystems which suggest that even at low PPFD the AOX is essential for optimal photosynthesis. In a posterior work, Yoshida et al. (2007) propose that the major physiological function of AOX is to serve as an electron sink that prevents over-reduction of the photosynthetic apparatus and thereby mitigates photoinhibition under excess PPFD. So, AOX activity in plant mitochondria becomes an essential accessory for stabilizing the autotrophic system of higher plants.

\begin{tabular}{|c|c|c|c|c|c|c|}
\hline \multicolumn{7}{|c|}{ Respiratory capacities } \\
\hline Treatment & $\left(\mu \mathrm{mol} \mathrm{O}_{2} \mathrm{~g}^{-1} \mathrm{DW} \mathrm{h}^{-1}\right)$ & $\begin{array}{c}\mathrm{Vc}_{\mathrm{yt}} \\
\left(\mu \mathrm{mol} \mathrm{O} \mathrm{g}^{-1} \mathrm{DW} \mathrm{h}^{-1}\right)\end{array}$ & $\begin{array}{c}\mathrm{V}_{\mathrm{AOX}} \\
\left(\mu \mathrm{mol} \mathrm{O} \mathrm{g}^{-1} \mathrm{DW} \mathrm{h}^{-1}\right)\end{array}$ & $\begin{array}{l}\mathrm{V}_{\text {Cyt }} / \\
\mathrm{V}_{\text {AOX }} \\
\text { (ratio) }\end{array}$ & $\begin{array}{l}\mathrm{V}_{\text {Cyt }} / \\
\mathrm{Vt} \\
(\%)\end{array}$ & \begin{tabular}{c|}
$\mathrm{V}_{\mathrm{AOX}}$ \\
$/ \mathrm{Vt}$ \\
$(\%)$
\end{tabular} \\
\hline Irrigated & $46.9 \pm 4.6$ & $23.1 \pm 2.9$ & $15.2 \pm 2.1$ & 1.5 & 49 & 32 \\
\hline Drought & $90.8 \pm 5.7$ & $31.3 \pm 1.8$ & $60.7 \pm 5.3$ & 0.5 & 34 & 67 \\
\hline
\end{tabular}

Table 2. Measurement of the capacities of respiratory pathways in Cabernet Sauvignon leaves. Rates were calculated from data of figure 1. Residual respiration $\left(\mathrm{O}_{2}\right.$ uptake in the presence of $1 \mathrm{mM} \mathrm{KCN}+10 \mathrm{mM}$ SHAM was subtracted from all values. $\mathrm{Vt}$ is the rate of $\mathrm{O}_{2}$ uptake in the absence of inhibitors, $\mathrm{V}_{\mathrm{Cyt}}$ is the capacity of the cytochrome pathway estimated as inhibition in the presence of $10 \mathrm{mMSHAM}, \mathrm{V}_{\mathrm{AOX}}$ is the capacity of the AOX pathway estimated as inhibition in the presence of $1 \mathrm{mM} \mathrm{KCN}$. All measurements were made in the fully expanded leaf. Values are means \pm SEM of three to four replicates.

Beyond the request of interaction of chloroplast with the mitochondria to obtain the greatest photosynthetic rate, it is now well established that mitochondrial electron transport is necessary to optimize photosynthesis (Padsmaree and Raghavendra, 1999; Dutilleul et al. 
2003; Noctor et al., 2004). Working with wheat Bartoli et al. (2005) showed that under drought the mitochondrial AOX pathway is up-regulated, and that is capable to maintaining photosynthetic electron transport under drought either by direct consumption of reducing power, by sustained production of $\mathrm{CO}_{2}$, or by allowing other power-consuming process to operate unabated. Thus, the nonphosphorylating pathways may function as a mechanism for plant photo-protection, but the components of this mechanism have not been characterized in detail. There are studies which that the AOX can efficiently respond to changes in the light environment such as ones developed by Svensson and Rasmusson (2001) and Finnegan et al. (1997) where AOx gene is induced by light in potato and soybean, respectively. Intrinsic interaction between photosynthesis and the respiratory chain has been observed in studies using specific inhibitors or mutants. In environments of high light and $\mathrm{CO}_{2}$ concentrations, better photosynthesis requires a continuous flow of metabolites through the calvin cycle and cytosolic sucrose synthesis. According Krömer et al. $(1988,1993)$ in barley protoplasts a low concentration of oligomycin (inhibitor of mitochondrial phosphorylation) diminished the photosynthetic rate, the Adenosine TriPhosphate/Adenosine Di-phosphate (ATP/ADP) ratio and the Triose Phosphate/3Phosphoglyceric Acid (TP/3-PGA) ratio. Some research refer that respiratory ATP is consumed by sucrose synthesis leading to an optimal rate of photosynthesis. Antimycin A (inhibitor of complex III) and SHAM (inhibitor of AOX) decreased the photosynthetic rate in pea mesophyll protoplast. The presence of antimycin A incresead TP/3-PGA ratio more than malate/oxaloacetic acid ratio, where in presence of SHAM the last one was strongly increased (Pdsmaree and Raghavendra, 1999). These findings suggest that the cytochrome pathway sustains the triose-phosphate export and the alternative pathway sustains the oxidation of malate in the light.

In leaves, the type and strength of the metabolic interconnections between chloroplast and mitochondria is broadly dependent on chloroplastidial nicotinamide adenine dinucleotide phosphate (NADPH) and ATP production driven by light energy. In turn, both ATP and NADPH are the driving force for carbon uptake, nitrogen assimilation and photorespiration. Already in the dark or in heterotrophic tissues the relationship between the plastids and mitochondria are distinct because the mitochondria is the main source of energy (Hoefnagel et al. 1998). However, independent of tissue type the mitochondria always preserve their basic function of being the powerhouse of the cell with the capacity for mitochondrial energy production being ubiquitous among contrasting tissues and developmental stages. Furthermore, another relevant point to be considered is the effect of water stress in electrons partitioning between cytochrome oxidase and alternative oxidase and its consequence in the ATP production. The mitochondrial electron transport chain (ETC) was more important than oxidative phosphorilation to optimize photosynthesis, particularly under low $\mathrm{CO}_{2}$ concentrations (Padmasree e Raghavendra, 1999). The importance of ETC mitochondrial to photosynthetic process was verified by reduced photosynthetic rate 20 a $30 \%$ in tobacco plants with impaired complex I (Dutilleul et al., 2003). In absence of complex I the contribution of ETC mitochondrial to glycine oxidation is reduced increasing extramitochondrial drain causing an increment in chloroplastidial reducing molecules and photosynthetic inhibition.

A main role of AOX is to balance the necessities of carbon metabolism and mitochondrial electron transport (Vanlerberghe and McIntosh, 1997) and under stress conditions its operation allows the TCA cycle to continue providing carbon skeletons for metabolism and synthesis of compatible solutes (Mckenzie and McIntosh, 1999). At the inner membrane of 
mitochondria AOX short cuts electron transport by transferring electrons directly from reduced ubiquinone to oxygen consequently the ATP production is diminished. Hence, part of the source for energy coupling is "wasted" as heat. On the other hand, AOX ignore adenylate and Pi control, and, under a high-energy charge, AOX assist to avoid incomplete reduction of oxygen to water as a source for reactive oxygen species. Thereby, AOX activity enables high turnover rates of carbon skeletons in the cytosol and the citric acid cycle at lower productivity levels of harmful reactive oxygen. Indeed, as photosynthesis decreased under water stress, an excess of reducing power is frequently generated and thus over-reduction of photosynthetic electron chain may result in oxidative burst. Thus, the AOX has been the focus of many studies in plant respiratory metabolism under several environmental stresses, mainly because an increase in AOX capacity might contribute to controlling the formation of reactive oxygen species (ROS) (Wagner, 1995; Popov et al., 1997; Maxwell et al., 1999; Umbach et al., 2005). At least part of the drought effects on plant physiology is related to ROS formation, such as superoxide $(\mathrm{O} 2--)$, hydrogen peroxide $\left(\mathrm{H}_{2} \mathrm{O}_{2}\right)$, hydroxil radicals $(\cdot \mathrm{OH})$ and singlet oxygen $\left({ }^{1} \mathrm{O}_{2}\right)$ ( $\mathrm{Li}$ and Staden, 1998). These ROS may initiate destructive oxidative process such as lipid peroxidation, chlorophyll bleaching, protein oxidation, and damage to nucleic acids (Scandalios, 1993). Water stress invariably decreases the photosynthetic rate and the intensity of this effect influences the capacity of different species to cope with the drought, which also depends on the duration of stress and plant genetic background (Kaiser, 1987; Chaves, 1991, Chaves et al., 2002). Generally, when respiration rate decreases upon drought conditions the photosynthesis and growth requirements are further affected. Nevertheless, this behavior seems to be somewhat species dependent, and respiratory rates can also increase, particularly under severe drought (Gashghaie et al., 2001; Flexas et al., 2005).

Has long be known that the mitochondria are the main source of cellular ROS, and a number of environmental stress that increase ROS production in plants also leads to an increase alternative pathway respiration. Culture of plant cells and fungi showed an increased in AOX activity in response the addition of hydrogen peroxide to the culture medium (Wagner, 1995; Vanlerberghe and McIntosh, 1996). Furthermore, essays with isolated soybean and pea mitochondria showed that additions of AOX inhibitors like as SHAM and $n P G$ induce $\mathrm{H}_{2} \mathrm{O}_{2}$ production (Popov et al. 1997). Under abiotic stress plants unavoidably undergo a disruption of cellular homeostasis with predictable consequences for the functioning of mitochondria, including their ability to regulate cellular energy status to cope with unfavorable conditions and during recovery. Soon, due the key role of mitochondria in plant cells, one might expect that cells with impaired mitochondria should not be able to survive stress. As discussed previously, respiration is generally affected by drought, but in a lesser extent than photosynthesis which fits well with the essential role of mitochondria. In water-stressed wheat seedlings pretreated with $1 \mathrm{mM}$ SHAM there was more generation of ROS than seedling either subjected to drought or SHAM treatment alone did (Feng et al. 2008). In addition, 1 mM SHAM did not significantly change the activity of peroxidases in drought leaves but inhibited most of AOX activity, evidencing that AOX inhibition lead to additional ROS production under drought conditions.

As far as water stress is an issue, it is interesting to focus at models that show adaptation to dryness, such as drought-resistant species and desiccation-tolerant organisms such as resurrection plants and orthodox seeds. In the meantime, mitochondrial biology in refer to water stress has been extensively studied in durum wheat a drought-tolerant cereal (Bartoli et al. 2005; Pastore et al. 2007). Analyzing messenger ribonucleic acid (mRNA) expression of 
AOX in Arabidopsis Clifton et al. (2006) show that five Aox genes are expressed with organ and development regulation, suggesting regulatory specialization of AOX genes members. Moreover, studying genes coexpressed with AOXs in response to various treatments that modify mitochondrial functions and/or in plants with altered AOX levels reveals that this gene set encodes more functions outside the mitochondrion than in mitochondria itself (Clifton et al. 2006). Despite this, the authors concluded that this have a role in reprogramming cellular metabolism in response to constant changing environment encountered by plants. The changes in the efficiency of energy coupling (amount of total respiration and AOX) induced by environmental stress are proposed to keep growth rates constant even a change to more unfavourable conditions (Hansen et al. 2002). The AOX pathway is regarded less efficient in energy conservation, so the authors propose that less-efficient metabolism in terms of energy coupling might be more efficient in terms of growth stability.

The optimizing metabolic efficiency for adaptive regulation of growth and development seems to be partly regulated by differential activity of AOX pathway. Order to verify the potential role of AOX as marker for stress tolerance a schematic global strategy for future experimentation on AOX was proposed by Arnholdt-Schmitt et al. (2006). Firstly, the system analyses and ecophysiological modeling should be carried out at the whole plant level to determine the importance of identifiable yield determining parameters as a basis for molecular research. This work has to be carried out at the species levels and should regard the interaction between developmental stages and the environment. Stress adaptation may results of sustaining growth by maintaining homeostase, down-regulating growth by avoid nutrient imbalance or up-regulating growth by induced secondary root growth and root hair formation. To breeding a growth adaptation efficient is a function of its effect on yield stability and in accordance of modeling; responsive tissues and cells should be identified parameters and will then be available for AOX analyses.

\section{Changes in sugar metabolism in response to low water availability}

As discussed in the previous section, drought alters the production and consumption of photoassimilates, so not surprisingly, the carbon partitioning between leaves itself and others plants organs will also be affected. The partitioning of photoassimilate is the result of a coordinated set of processes of anabolism and transport between source/sink and is under the control of genetic, environment and development factors (Chaves, 1991). The amount of carbon that will be available for storage, maintenance and transport is determined by regulatory processes in the sources leaves. Part of this process, referred as metabolic control of the of triose-phosphate export from the chloroplast for the synthesis of sucrose in the cytosol, it is reasonably comprehensible (Stitt and Quick, 1989). Sucrose, a main product of photosynthesis, is the major form of translocated carbon and the most important substrate for sink metabolism. In full expanded leaves, the carbon is split between leaf itself and the whole plant, already in mature leaves, the majority of carbon is translocated to another parts of plant. In accordance to Huber and Huber (1996) sucrose contents in leaf is determined by several factors including the rate of photosynthesis, the partitioning of photosynthetic carbon between starch and sucrose, the rate of sucrose hydrolysis and the rate of sucrose export. The sucrose contents in leaves can imply the existing availability of carbon assimilates for growth and development, since this sugar is both, the principal and the preferred form of photoassimilate for transport to sink organs (Liu et al. 2004). 
Under water stress is a strong decreased in starch content, inactive osmotically, and concomitant increase in soluble sugars, osmotically active, which provide the lowering the osmotic potential and contributes to maintenance of leaf water status (Pelleschi et al. 1997; Pinheiro et al. 2001; Yang et al. 2001). Moreover, according Bray (1997) sugars are energy and carbon sources required for defense response and water stress adaptation, hence, the higher supply of these molecules is necessary for plant survival in this condition. When reserve polysaccharides are mobilized, often has sucrose as a product of hydrolysis. The drought modifies the carbon partitioning between starch and sucrose synthesis and the sucrose/starch ratio can increase 2 or 3 fold (Quick et al. 1989, 1992; Vassey and Sharkey, 1989). Plants of grapevine cv. Cabernet Sauvignon exposed to severe stress showed decreases in leaf starch levels with fall in $\neg \mathrm{W}$, so, as a consequence of increased synthesis versus starch breakdown higher levels of sucrose were expected. However, the drought leads to reductions of $32 \%$ in the levels of sucrose, but, the sucrose/starch ratio increased from 0.54 to 0.69 in control and dryness plants, respectively (table 3 ). This increase being more directly related to starch reduction than sucrose synthesis itself. Moreover, the decrease in leaf water potential reduced $18 \%$ in the SPS activity and increased $60 \%$ in the vacuolar acid invertase activity (Figure 2). In leaves, sucrose content is dependent on its synthesis catalyzed by sucrose phosphate synthase (SPS) and its breakdown catalyzed by invertases. The employ and allocation of sucrose for different pathways and different cellular compartments are greatly dependent on the physiological and biochemical requirements of tissues: 1) driven to glicolytic way and tricarboxylic acid cycle to produce ATP and NADH; 2) employed in biosynthesis of primary metabolites essential for growth and development; 3) converted in polymers such starch, triacylglycerides or polypeptides for long-term storage or 4) converted in secondary compounds enabling the plants to produce with predators, pests and environment changes. Many of these processes can occur simultaneously in the same compartment, so the allocation of sucrose for such events requires a mechanism of precise control. The use of sucrose as a source of carbon and energy depends on their breakdown into hexoses, and in plants either sucrose synthase (SS) or invertase catalyze this reaction. Invertase (EC 3.2.1.26, $\beta$-fructofuranosidase) is a hidrolase and cleaving sucrose into glucose and fructose, whereas SS (EC 2.4.1.13) is a glycosyl transferase that in presence of Uridine Diphosphate (UDP) cleaving sucrose into UDPglucose and fructose (Sturm, 1999). Plants have two classes of invertase, which differ by their optimum $\mathrm{pH}$, being alkaline invertase (AI) with maximal activity at $\mathrm{pH} 7.0$ located in the cytoplasm, and the acid isoforms with optimum activity at $\mathrm{pH}$ around 5.0 and at least two subcellular locations. Most plants have at least two isoforms of vacuolar invertase, which accumulate as soluble proteins (soluble acid invertases) in the lumen of this acidic compartment and several isoforms of extracellular invertase that are ionically bound to the cell wall (Sturm, 1999).

\begin{tabular}{|c|c|c|c|}
\hline Treatment & $\begin{array}{c}\text { Starch } \\
\left(\mu \mathbf{g ~ g}^{-1} \mathbf{~ F W}\right)\end{array}$ & $\begin{array}{c}\text { Sucrose } \\
\left(\mu \mathbf{m o l ~ g}^{-1} \mathbf{~ F W}\right)\end{array}$ & $\begin{array}{c}\text { Glucose } \\
\left(\mu \mathrm{mol} \mathrm{g} \mathbf{~}^{-1} \mathbf{F W}\right)\end{array}$ \\
\hline Irrigated & 0.4 & 300 & 254 \\
\hline Drought & 0.1 & 164 & 153 \\
\hline
\end{tabular}

Table 3. Starch, sucrose and glucose levels measured in Cabernet Sauvignon under severe water stress. 

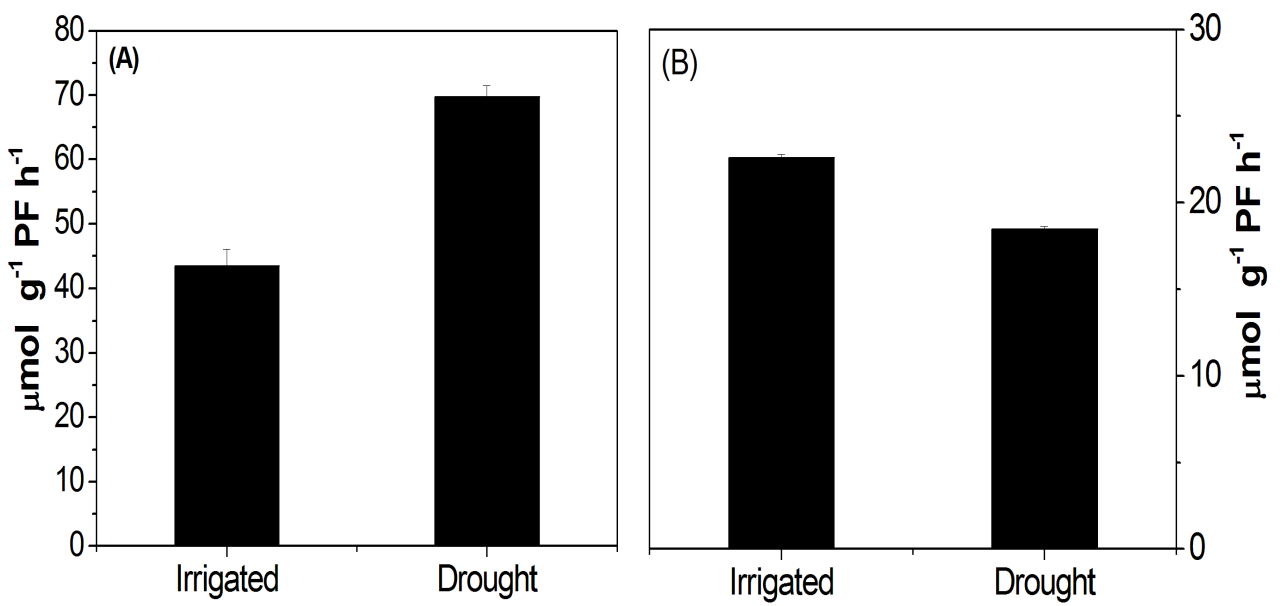

Fig. 2. Invertase activity (A) and sucrose phosphate synthase activity measured in cabernet sauvignon under severe stress.

The role of invertases is extremely important for many cellular processes, such as for example, their involvement in phloem loading and unloading, the involvement in plant defense response to stresses and recovery of turgor for cell expansion (Sturm and Tang, 1999). Sugars and invertases are crucial for reproductive development under drought. In several parts of the world, reproductive crops are the mainstays of agriculture being large extensions devoted to grain, fruit, nuts, flowers and so on. During the production cycle of plants, it is vitally to maintain these structures, especially under environment unfavorable conditions. In virtually all crops, water stress can trigger a smaller floral development or induce aborts when occurred around the time of pollination. Even if occurs the rehydration by rain or irrigation management, there is no resumption of floral growth and the abortion will irreversible. The result is fewer grains or fruits, but, if dryness is delayed until later in reproduction, abortion may not occur and, instead, floral and fruit development may diminish reversible (Saini and Westgate, 2000; Boyer and Westgate, 2004). After phloem unloading in sinks, sucrose is translocated to recipient cells through either the apoplastic pathway (cell wall matrix) or symplastic pathway (via plasmodesmata). The apoplastic pathway is effective at various points during development of most of reproductive organs where CWIN is characteristically expressed to hydrolyse extracellular sucrose. The cell wall invertase (CWIN) and vacuolar invertase (VIN) are associated to the earliest phases of flower development and the activity supplies hexoses to developing anthers and ovaries before pollination occurs. Recipient cells in sinks receive the hexose released from CWIN activity through hexose transporter (HT) and co-expressinon o CWIN and HT has been observed in many systems (Roitsch and Gonzalez, 2004).

Tissue elongation can be attributed to both process cell division and cell expansion, and it is believed that vacuolar invertase plays a role in cell expansion. But, it is difficult to obtain direct evidence for this, mainly due the multi-cellular nature of plant tissues where a given cell type is often deeply embedded and thus not readily accessible for harvest and measurement. It is believed that the invertase act in cell expansion by promoting the osmotic regulation (Roitsch and Gonzales, 2004; Sergeeva et al., 2006). This is possible because 
through its activity invertase hydrolyzing sucrose into two hexoses which doubles the osmotic contribution thus favoring water influx to drive cell expansion. The invertase activity in response to water stress present different patterns, which vary according to the intensity of the stress and the species studied. According to Zinselmeier et al. (1995), the increased in soluble and insoluble invertase activity during pollination and grain development of maize was blocked by water stress. This was correlated with low levels of reducing sugars, increased in sucrose contents, starch depletion and growth inhibition of ovarian culminating in abortion. However, there was strong accumulation of hexoses correlated with induction of vacuolar invertase activity in leaves of maize exposed to water stress (Peleschi et al. 1997). These results show that the response of invertase to water stress is specific to tissue and organ. In addition, in leaves of Lupinus albus L. the activity of vacuolar and cytosolic invertases and soluble sugar levels increased 6 days after water suspension, being the magnitude of the increased more pronounced in leaf blade (Pinheiro et al. 2001). In hydrated maize plants except cell wall invertase, the activity of other enzymes responsible for hydrolysis of sucrose is higher in sink than in source leaves, being none detected or only marginal effect of water stress on the activity of CWIN, CIN and SS in both organs (Kim et al. 2000). But, the water stress has caused a remarkable increase in VIN in mature leaves, leaf sheath and primary roots. In maize under drought, the most pronounced activity of VIN was due Ivr2 gene expression (Peleschi et al. 1999; Kim et al. 2000), while none of the other genes encoding both the soluble (Ivr1) and insoluble (Incw1, Incw2, Incw3, Incw4) form were expressed or modulated (Kim et al. 2000).

The buildup of sucrose and hexoses in source leaves may have several consequences, such as change in cellular osmotic potential and modulation of the expression of various genes of carbohydrate metabolism. According Sturm and Tag (1999) sucrose and its hydrolysis hexoses have crucial role in several signal transduction pathways. Because are sessile, plants have few alternative to survive and/or acclimate to environment changing, then are highly sensitive and responsive. Thus, the genes regulation by carbohydrates represents a valuable mechanism for adaptation to environment failures (Smeekens, 2000; Rolland et al. 2006). The sugar concentration in plant tissues varies over wide range, which typically exceeds that found in other homeostatic systems, such as the blood of mammals. This provides the plants with broad spectrum of signs and great capacity for adjustment. The effects of carbohydrate availability on the expression of specific genes enable and amplify the possible interference of more immediate metabolic control. In general way decreases in carbohydrate levels increase gene expression of photosynthetic process (Sheen, 1990; Krapp et al; 1993; Ehness, 1997) and storage mobilization/translocation (Ho et al. 2001; Conde et al. 2006). On the other hand, high levels of carbohydrate lead the expression of storage and consumption genes (Roitsch et al. 1995; Atassanova et al. 2003).

Abscisic acid (ABA), a important component of several signal transduction pathway of stress response led increases in invertase activity when exogenously applied in soybean green beans (Ackerson, 1985) and maize leaves exposed to drought (Trouverie et al. 2003). Abscisic acid induces not only increases in VIN activity but also the expression of Ivr2 in leaves and root maize (Trouverie et al. 2004). Some methodical and striking research of the sugar-ABA interface have been carried out recently and hexose-based signals originating from sucrose cleavage are implicated in regulation of ABA biosynthetic genes (Gazarrani and McCourt, 2001). Like the several role exerted by the sucrose, eg. nutrition, osmoregulation and signaling, plant invertase may have different functions. Often, this 
enzyme hydrolyzes sucrose into hexoses providing fuel for respiration as well carbon and energy for the synthesis of diverse compounds. The cleavage of sucrose into glucose and fructose causes a marked increase in osmotic pressure of cells, suggesting a possible role of invertase in cell elongation and plant growth (Sturm and Tag, 1999). Thus, in water stress conditions the invertase can act as mediators in the process of osmotic adjustment required for the survival of plant.

\section{Water-saving irrigation and plant metabolism}

It is known that many crops have high water requirements and supplemental irrigation is necessary to achieve the optimal production rates. According to actually scenario of climate changing and future predictions the demand for irrigation will increase considerably in years to alleviate the consequences of these changes. Nevertheless, as a consequence of global climate changes and environment pollution, water for agriculture has been limited in many regions (FAO, 2003). Because of this, water resources saving and increasing agricultural productivity per unit of water are becoming of a strategic importance for many countries. Irrigation is applied for preventing water deficits that reduce crop yield. The crop water use has two major components related to water loss: evapotranspiration (ET) that represents evaporation losses from the soil and crop and other losses that result from the distribution of water to the land. An important fact is that all irrigation water contains salts and, as water evaporates, salts concentrate in soil profile and must be displaced below the root zone before they reach a concentration that limits crop yield. Salt leaching is achieved by the movement of water applied in excess of evapotranspiration and some of water losses are unavoidable and are needed to maintain the salt balance. So, this effect can be minimized with efficient irrigation methods and by appropriate management. The evaporation from crop canopies is strongly attached with carbon assimilation (Steduto et al. 2009), so diminishing ET without deleterious effects in crop yield is so difficult. A restraint in water supply that decreases transpiration under the rate dictated by the evaporative demand of the atmosphere is paralleled by a reduction in biomass gain.

Thus, improving management irrigation is most likely the best option in most agricultural systems for increasing the efficiency of water use (Steduto et al. 2007). Deficit irrigation (DI) and partial root-zone drying (PRD) are water-saving irrigation strategies. The practice of water supply below the ET requirements is termed deficit irrigation (DI), where the irrigation is reduced relative to that needed to meet maximum ET and the mild stress has minimal effects on the crop productivity (English, 1990; English and Raja, 1996). Thus, water employed for irrigation can be reduced and the water saved can be diverted for another uses. In areas of frequent water scarceness and long drought periods the application of DI is a common practice; however, an effective use of DI requires prior knowledge of specific crop-growth stages showing tolerance to water stress. Moreover, the decreasing in the water improvement for irrigation to an area requires a lot of adjustments in agricultural system. PRD is a further refinement of DI; which involves irrigating only half of the root zone leaving the other to dry to a predetermined level before alternating irrigation. The PRD practice can save up to $50 \%$ of irrigation water with only a marginal yield reduction in tomato (Kirda et al. 2004). So, accumulated evidence has demonstrated that, given a same amount of irrigation water, PRD is superior to DI in terms of yield maintenance and increase WUE (Dodd 2009; Wang et al. 2010). Wang et al. (2009) reported that in potatoes plants total $\mathrm{N}$ content leaf layer was significantly higher for PRD than for the DI and full irrigated (FI). 
However, the increment of tuber dry weight was similar for all the irrigation treatments; as a result the WUE was similar for the PRD and DI treatments and which was significantly greater than that for FI treatment.

Results of Mingo et al. 2004 showed that PRD tomato plants achieved biomass equivalence with FI plants but in PRD plants translocation of dry matter from leaves and stems was increased which led increase of root biomass by $19 \%$. Has been shown that the exposure of roots to soil drying and soil re-watering increases root growth (Laing et al. 1996) and that PRD increase root growth of grapevine plants (Dry et al. 2000). The conservative vision of drought is that soil drying induces restriction of water supply and this outcome in a sequential reduction of tissue water content, growth and stomatal conductance. Definitely this is the case, and in some events changes occurred in leaf physiology are more closely associated to the changes in soil water content (Passioura, 1988). This sort of reaction demands that the plants have certain mechanism for sensing the soil water content and regulating stomatal aperture and leaf growth accordingly. This might involve transfer of chemical signal from the roots to shoots through xylem and such control has been called chemical signaling (Jones, 1980). Both practices, PRD and DI led the ABA-based root-toshoot chemical signaling regulating stomatal conductance and leaf expansion growth thereby increasing WUE (Dodd, 2007; Wang et al. 2010). But, earlier studies indicated that in a similar soil water deficit, PRD can intensify ABA signaling relative to the DI treatment resulting in better control of plant water loss causing further improvement of WUE (Dodd, 2007; Wang et al. 2010). PRD can stimulate root growth and maintain a constant ABA signaling to regulate shoot physiology; whereas plants under DI some of the roots in dry soils for long period may die and signaling may diminish and shoot water deficits may occur (Kirda et al 2004; Davies and Hartung, 2004).

Beyond saving water and improvement WUE, various researches have demonstrated that PRD may improve fruit quality (dos Santos et al. 2003; Zgebe et al. 2006; Treeb et al. 2007; Jensen et al. 2010). Although the physiological reasons for such event remain unclear, it is suggested that improved crop nutrient status may partly be responsible for the higher crop quality under the PRD treatment (Shahnazari et al. 2008). The authors predicted that PRD led to less mineral $\mathrm{N}$ left in the soil and the crop showed a clear "stay green" phenomenal late in the season, and might have contributed to the higher marketable tuber yield. In agreement, Wang et al. (2009) observed that PRD significantly increased the total N content in leaves, stems, and tubers of potato plants compared with FI and DI treatments. Another crop, like maize and wheat has also been denoted an increase in $\mathrm{N}$ uptake under PRD irrigation (Kirda et al. 2005; Li et al. 2005). Nevertheless, PRD does not improve N uptake in plants of maize (Hu et al. 2009) and tomato (Topcu et al. 2007) not being clarified the reasons for this discrepancy.

The PRD technique has been applied in several studies related to distinct culture such potato, tomato, soybean, wheat, olive and so on. But, to Vitis vinifera L plants which the production is frequently dependent on irrigation the technique is now undergoing extensive commercial trials. The main effects of PRD in grapevine are that water use efficiency is increased, vegetative vigour is reduced while crop yield and berry size are not significantly reduced. The reduction in canopy density can result in better light penetration to the bunch zone and a consequent improvement in grape quality (Dry et al. 1996). So, the concept to use PRD as a tool to manipulate water deficit responses in this way had its origin in the observation of Loveys and During (1984) who the root-derived ABA signal was important to 
grapevine stomatal conductance. Thereafter, Gowing et al. (1990) showed that split-root plants could be used to show that many of the effects of water stress could be explained in terms of the transport of chemical signals from root to shoot without changes in water relations. The management of irrigation allows manipulating vegetative development if both wet and dry root zones could be maintained (Loveys, 1991). The necessary chemical signals would derive from the dry roots and water supplied from the wet roots would prevent the development of severe water deficit. In a pot experiment where a comparision was made between partial and complete rootzone drying, partial drying resulted in an $80 \%$ reduction in stomatal conductance an $60 \%$ in leaf ABA content whereas when a similar reduction in gs occurred in response to drying the entire root system foliar ABA increased 5fold (Stoll et al. 2010). According Loveys et al. (2000) the changes in ABA content of grapevine roots exposed to drying soil not necessary translate to an equivalent change in leaf ABA. The amount of ABA accumulated in leaves may not be important in determining stomatal conductance but the levels of $\mathrm{ABA}$ in the xylem is the important factor that control stomatal aperture (Jia and Zhang, 1999). Both, the high concentration of ABA in the xylem and the increase in xylem sap $\mathrm{pH}$ in PRD vines may contribute to greater transpiration efficiency and regulation of stomatal conductance (Stoll et al. 2010).

One of the greatest strengths of PRD over other forms of deficit irrigation is the better control of vegetative growth without reduction in fruit yield and quality (Santos et al. 2003). Frequently, this control is associated to reduce total leaf area index in response to PRD application (Santos et al. 2003; Liu et al. 2006). So, a lowest green leaf area will not only reduce transpiration but can also reduce photosynthesis due to less light capture. But, in some studies the PRD treatment have not influenced the photosynthetic rate (Aganchich et al. 2009; Melgar et al. 2010). As discussed previously in this chapter water deficits can affect photosynthesis and reduce carbon photoassimilates in source leaves. The response of plant growth is closely related to carbon supply and allocation within its organs, and under water deficit the export of photoassimilates from source leaves to sink organs is reduced and the competition for assimilates among the organs is modified. As a result, carbon assimilation, partitioning and plant growth changes in response to water deficit, since the growth of any specific sink organ especially reproductive organ, depends mostly on the carbon assimilates available to the organ. Opposed to a simple water deficit treatment, DI scheduling is often applied by withholding water specifically in periods when organ of the plant with economic value (eg. Fruit, grain, root...) is less sensitive to water deprivation. Although, the responses of carbon allocation to water stress are well clarified, there is still a lack of knowledge about how PRD and DI interfere allocation patterns of carbon assimilates.

Deficit irrigation is more frequent applicable in tree crops and vines because economic returns be higher in fruit trees than in field crops. When tested in tomatoes, PRD saved up $50 \%$ of the irrigation water and caused a marginal reduction in yield with reduced leaf area index and vegetative growth suggesting that photosynthesis assimilates were predominately partitioning to fruit growth so that significant yield reduction was prevent (Kirda et al. 2004). According to yours findings the authors suggest that PRD can be viable and beneficial option with the conventional DI to avoid crop-yield reductions when and if there is water shortage. Moreover, high crop yield can be maintained under water scarcity if the PRD is applied, so are still needed more studies to test yield responses of other horticultural, field and tree crops with a high-irrigation-water requirement. However, when applying the deficit irrigation is important to know the low, medium and drought-tolerant 
growth stage to optimize the reduction of water that can be deployed. In various cases PRD is capable to maintain a elevated yield as well as higher quality and thereby a elevated water saving per produced unit than DI. Higher local soil water flow might be present and higher nitrogen mineralization occurred under PRD as compared with DI influencing the transport of nutrients to the root surfaces (Jensen et al. 2010).

Although it has shown positive results for some crops, many tests are required with the practice of PRD does occur before its implementation on a commercial scale. So far, the most valued characteristics in studies of PRD and DI applied are WUE and the gas exchange and in some cases the crop yield and quality. However, there is a great gap about the behavior of sugar partitioning between organ source and organ sink as well as activity of key enzymes of this process, in cellular respiration and in other processes related to cellular energy in response to DI and PRD applied. Even though there studies showing few or no modification on gas exchange in plants exposed to DI or PRD failure to elucidate the physiological mechanisms responsible to this. Given the fact that production (photosynthesis) partitioning (sugar metabolism) and consumption (respiration) are the mainstays to plant growth and development, studies of such processes in plants exposed to DI or PRD is extremely important to support the recommendation of this technique.

\section{Conclusion}

Actually, more than told the global climate change has been experienced by all living organisms, especially the plants because they are sessile. In this scenario a major concern in the plant science community is the aridity increasing ever more reducing water availability for agriculture practices. The plants respond quickly to reduced water potential in soil and atmosphere by altering several metabolic reactions, physiological process and genes expression, where the first one is the decrease in stomatal aperture. Photosynthesis and respiration are closely related process, and obviously the changes in plant growth elicited by reduced water availability have been associated to modulations between the production and consumption of carbon. Furthermore, another strong implication to plant development inherent drought is the impaired partitioning of carbon between the leaf and others organs. So, before this situation the development of suitable irrigation managements in order to maintain crop yield without impaired quality and avoidance water waste is an important issue worldwide. Some research employing irrigation management like deficit irrigation and partial root-zone drying techniques has been widely investigated with promising results but somewhat conflicting. Although, the major works employing DI and PRD technique were performed in perennial crops, with a few works in horticultural crops. Moreover, the results obtaining by these irrigation management are mainly related to quality and water use efficiency, being required studies on the parameters of production (photosynthesis), consumption (respiration) and partitioning (sugar metabolism) of carbon.

\section{References}

Abreu, M.E. \& Munné-Bosch, S. (2008). Salicilic acid may be involved in the regulation of drought-induced leaf senescence in perennials: A case study in field-grown Salvia officinalis L. plants. Environmental and Experimental Botany, 64, 105-112.

Ackerson, R.C. (1985). Osmoregulation in Cotton in response to water stress. III. Effects of phosphorus fertility. Plant Physiology, 77, 309-312. 
Aganchich, B. Wahbl, S., Loreto, F., \& Centritto, M. (2009). Partial root zone drying: regulation of photosynthetic limitations and antioxidant enzymatic activities in young olive (Olea europaca) saplings. Tree Physiology, 29, 685-696.

Alscher RG, Donahue JL, \& Cramer CL. (1997). Reactive oxygen species and antioxidants: relationships in green cells. Physiologia Plantarum, 100, 224-233.

Arnholdt-Schmitt, B., Costa, J.H. \& de Melo, D.F. (2008). AOX - a functional marker for efficient cell reprogramming under stress? Trends In Plant Science, 11, 281-287.

Asseng, S., \& Hsiao TC (2000). Canopy $\mathrm{CO}_{2}$ assimilation, energy balance, and water use efficiency of an alfalfa crop before and after cutting. Field Crops Research, 67, 191-206.

Atassanova, R., Leterrier, M., Gaillard, C., Agasse, A., Sagot, E., Coutos-Thévenot, P. \& Delrot, S. (2003). Sugar-regulated expression of a putative hexose transport gene in grape. Plant Physiology, 131, 326-334.

Bartoli, C.G., Gomez, F., Gergoff, G., Gulaét, J.J. \& Puntarulo, S. (2005). Up-regulation of the mitochondrial alternative oxidase pathway enhances photosynthetic electron transport under drought conditions. Journal of Experimental Botany, 56, 1269-1276.

Bartoli, C.G., Pastori, G.M. \& Foyer, C.H. (2000). Ascorbate biosynthesis in mitochondria is linked to the electron transport chain between complexes III and IV. Plant Physiology, 123, 335-343.

Bartoli, CG, Pastori, GM \& Foyer, CH (2000). Ascorbate biosynthesis in mitochondria is linked to the electron transport chain between complexes III and IV. Plant Physiology, 123, 335-343.

Blum, A (1998). Improving wheat grain filling under stress by stem reserve mobilization. Euphytica, 100, 77-83.

Bota, J., Medrano, H. \& Flexas, J. (2004). Is photosynthesis limited by decreased rubisco activity and RuBP content under progressive water stress? New phytologist, 162, 671-681.

Boyer, J.S., \& Westgate, M.E. (2004). Grain yields with limited water. Journal of Experimental Botany, 55, 2385-2394.

Bray, E.A. (1997). Plant responses to water deficit. Trends in Plant Science, 2, 48-54.

Brounleader, M.D., Harbone, J.B. \& Dey, P.M. (1997). Carbohydrate metabolism: Primary metabolism of monosaccharides. Chapter 3. In: DEY P.M. \& HARBORNE J.B. Eds. Plant Biochemistry, 111-140.

Chaves, M.M., Maroco, J.P., \& Pereira, J.S. (2003). Understanding plant response to drought: from genes to the whole plant. Functional Plant biology, 30,239-264.

Chaves, M.M., \& Oliveira, M.M., (2004). Mechanisms underlying plant resilience to water deficits: prospects for water-saving agriculture. Water-saving in Agriculture Special issue. Journal of Experimental Botany, 55, 2365-2384.

Chaves, M.M., Pereira, J.S., Rodrigues, M.L., Ricardo, C.P.P., Osório, M.L., Carvalho, I., Faria, T., \& Pinheiro, C. (2002). How plants cope with water stress in the Field: photosynthesis and growth. Annals of Botany, 89, 907-916.

Chaves, MM, Flexas, J. \& Pinheiro, C. (2009). Photosynthesis under drought and salt stress: regulation mechanisms from whole plant to cell. Annals of Botany, 103, 551-560.

Chaves,M.M. (1991). Effects of water deficits on carbon assimilation. Journal of Experimental Botany, 42, 1-16. 
Chernyad'ev, LI.I. (2009). The protective action of cytokinins on the photosynthetic machinery and productivity of plants under stress (review). Applied Biochemestry and Microbiology, 45, 351-362.

Clifton R, Millar AH, \& Whelan J. (2006). Alternative oxidases in Arabidopsis: a comparative analysis of differential expression in the gene family provides new insights into function of nonphosphorylating bypasses. Biochimica et Biophysica Acta, 1757, 730741.

Conde, C., Agasse, A., Glissant, D., Tavares, R., Gerós, H.; \& Delrot, S. (2006). Pathways of glucose regulation of monosaccharide transport in grape cells. Plant Physiology, 141, 1563-1577.

Cornic, G. (2000). Drought stress inhibits photosynthesis by decreasing stomatal aperture not by affecting ATP synthesis. Trends in Plant Science, 5,187-188.

Cornic, G., \& Briantis, J.M. (1991). Partitioning of photosynthetic electron flow between $\mathrm{CO}_{2}$ and $\mathrm{O}_{2}$ reduction in a $\mathrm{C}_{3}$ leaf (Phaseolus vulgaris L.) at different $\mathrm{CO}_{2}$ concentration and during drought stress. Planta, 183, 178-184.

Davies, W.J., \& Hartung, W., (2004). Has extrapolation from biochemistry to crop functioning worked to sustain plant production under water scarcity? In: Proceeding of the Fourth International Crop Science Congress, 26 September-

Day, DA, Dry, IB, Soole, KL, Wiskich, JT, \& Moore, AL (1991). Regulation of alternative pathway activity in plant mitochondria. Plant Physiology, 95, 948-953.

Dodd IC (2007). Soil moisture heterogeneity during deficit irrigation alters root-to-shoot signaling of abscisic acid. Functional Plant Biology, 34, 439-448.

Dodd, IC (2009). Rhizposphere manipulations to maximize 'crop per drop' during deficit irrigation. Journal of Experimental Botany, 60, 1-6.

Dos Santos, T.P., Lopes, C.M., Rodrigues, L., de Souza, C.R., Maroco, J.P. Pereira, J.S., Silva, J.R. and Chaves, M.M (2003). Partial rootzone drying: effects on growth and fruit quality of field-grown grapevines (Vitis vinifera L.). Functional Plant Biology, 30: 663-671.

Dry, P.R., Loveys, B.R., Botting, D. and During, H. (1996) Effects of partial root-zone drying on grapevine vigour, yield, composition of fruit and use of water. Proceedings of the $9^{\text {th }}$ Australian Wine Industry Technical Conference, 126-131.

Dry, P.R., \& Loveys, B.R., (1999). Grapevine shoot growth and stomatal conductance are reduced when part of the root system is dried. Vitis, 38, 151-156.

Dry, P.R., Loveys, B.R., \& During, H., (2000). Partial drying of rootzone of grape. I. Transient changes in shoot growth and gas exchange. Vitis 39, 3-7.

Dry, P.R., Loveys, B.R., McCarthy, M.G., \& Stoll, M., (2001). Strategic management in Australian vineyards. Journal International Sciences de la Vigne et duVin. 35, 129-139.

Dutilleul, C, Driscoll, S, Cornic, G, De Paepe, R, Foyer, CH \& Noctor, G (2003). Functional mitochondrial complex I is required by tobacco leaves for optimal photosynthetic performance in photorespiratory conditions and during transients. Plant Physiology, 131, 264-275.

Ehness, R., Ecker, M., Dietmute, E., Godt, E. \& Roitsch, T. (1997). Glucose and stress independently regulate source and sink metabolism and defense mechanism via signal transduction pathways involving protein phosphorylation. The Plant Cell, 9, 1825-1841. 
English M, \& Raja SN (1996). Perspectives on deficit irrigation. Agricultural Water Management, 32, 1-14.

English M. (1990). Deficit irrigation. I. Analytical framework. Journal of Irrigation and Drainage Engineering, 116, 399-412.

Erice,G, Louahlia, S, Irigoyen, JJ, SAnches-Diaz, M, Alami, TI \& Avice, J-C (2011). Water use efficiency, transpiration and net $\mathrm{CO}_{2}$ exchange of four alfafa genotypes submitted to progressive drought and subsequent recovery. Environmental and Experimental Botany, 72, 123-130.

FAO, 2003. AQUASTAT-Global information system on water and agriculture. Global Map of Irrigation Areas Serbia. See: http://www.fao.org/ES/ess/index.en.asp.

Feng, H, Li, H Li, X, Duan, J, Liang, H, \& Zhi, D, Ma, J (2007). The flexible interrelation between AOX respiratory pathway and photosynthesis in rice leaves. Plant Physiology and Biochemistry, 45, 228-235.

Finnegan, P.M., Soole, K.L., \& Umbach, A.L., (2004). Alternative mitochondrial electron transport proteins in higher plants. In: Day, D.A., Millar, A.H., Whelan, J. (Eds.), Plant Mitochondria: From Genome to Function. Kluwer Academic Publishers, Dordrecht, pp. 163-230.

Flexas, J. \& Medrano, H. (2002). Drought-inhibition of photosynthesis in $C_{3}$ plants: Stomatal and non-stomatal limitations revisited. Annals of Botany, 89, 183-189.

Flexas, J., Bota, J., Clifre, J.; Escalona, J.M., Galmes, J.; Gulias, J., El-Kadri Lefi; MartinezCantellas, S.F.; Moreno, T.; Ribas-Carbo, M.; Riera,D.; Sampol, B. \& Medrano, H. (2004). Understanding down-regulation of photosynthesis under water stress: future prospects and searching for physiological tools for irrigation management. Annals Applied Biology, 144, 273-283.

Flexas, J., Escalona, J.M. \& Medrano, H. (1999). Water stress induces different levels of photosynthesis and electron transport rate regulation in grapevines. Plant, Cell and Environment, 22, 39-48.

Flexas, J.; Galmés, J.; Ribas-Carbo, M. \& Medrano, H. (2005). The effects of water stress in plant respiration. Chapter 6. In: H lambers, M. Ribas-Carbo (Eds) Plant respiration: from cell to ecosystem, vol 18. Advances in photosynthesis and respiration: Series . p. 85-93.

Flexas, J.; Ribas-Carbo, M.; Bota, J.; Galmés, J.; Henkle, M.; Martinez-Cañellas, S, S. \& Medrano, H. (2006). Deceased rubisco activity during water stress is not induced by decreased relative water content but related to conditions of low stomatal conductance and chloroplast $\mathrm{CO}_{2}$ concentration. New Phytologist, 172, 73-82.

Flowers, M.D., \& Lal, R., (1998). Axle load and tillage effects on soil physical properties and soybean grain yield on a mollic ochraqualf in northwest Ohio. Soil Tillage Research, 48, 21-35.

Galmés, J., Medrano, H. \& Flexas, J. (2007). Photosynthetic limitations in response to water stress and recovery in Mediterranean plants with different growth forms. New Phytologist, 175, 81-93.

Gazarrani, S. \& McCourt, P. (2001). Genetic interactions between ABA, ethylene and sugar signaling pathways. Current opinion in Plant Biology, 4, 387-391.

Georgieva, K., Sárvári, E. \& Keresztes, A. (2010). Protection of thylakoids against combined light and drought by a luminal substance in the resurrection plant Harberlea rhodopensis. Annals of Botany, 105, 117-126. 
Ghannoum, O., Conroy, J.P., Driscoll, S.P.; Paul, M.J., Foyer, C.H. \& Lawlor, DW (2003). Nonstomatal limitations are responsible for drought-induced photosynthetic innhibition in four $\mathrm{C}_{4}$ grasses. New Phytologist, 159, 599-608.

Ghashghaie, J, Duranceau, M, Badeck, FW, Cornic, G, Adeline, MT, \& Deleens, E (2001). ${ }^{\delta_{13} \mathrm{C}}$

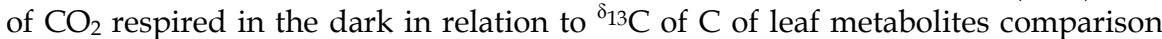
between Nicotiana sylvestris and Helianthus annuus under drought. Plant, Cell and environment, 28, 834-849.

Gowing, G.J., Davies, W.J., \& Jones, H.G. (1990). Regulated deficit irrigation of Cabernet Sauvignon grapevines. Australian New Zealand Wine Industry Journal, 5, 131-133.

Hansen, L.D., Church, J.N., Matheson, S., McCarlie, V.W., Thygerson, t., Criddle, R.S. \& Smith, B.N. (2002) Kinetics of plant growth and metabolism. Thermochimestry Acta 388: 415-425.

Haupt-Herting, S. \& Fock, H.P. (2000). Exchange of oxygen and its role in energy dissipation during drought stress in tomato plants. Physiologia Plantarum, 110, 489-495.

Haupt-Herting, S. \& Fock, H.P. (2002). Oxygen Exchange in relation to carbon assimilation in drought stressed leaves during photosyntheis. Annals of Botany, 89, 851-859.

Ho, S.L., Chao, Y.C., Tong, W.F. \& Yu, S.M. (2001). Sugar coordinately and differentially regulates growth-and stress-related gene expression via a complex signal transduction network and multiple control mechanisms. Plant Physiology, 125, 877890.

Hoefnagel, MHN, Atkin, OK, \& Wiskich, JT (1998). Interdependence between chloroplasts and mitochondria in the light and the dark. Biochimica et Biophysica Acta, 1366, 235255.

Huber, S.C. \& Huber, J.L. (1996). Role and regulation of sucrose-phosphate synthase in higher plants. Annual Review Plant Physiology and Plant Molecular Biology, 47, 431444.

Hund, A, Ruta, N \& Liedgens, M (2009). Rooting depth and water use efficiency of tropical maize inbred lines, differing in drought tolerance. Plant Soil, 318, 311-325.

Hura, T., Hura, K. \& Grzesiak, M. (2011). Soil drought applied during the vegetative growth of triticale modifies the physiological and biochemical adaptation to drought during the generative development. Journal of Agronomy and Crop Science, 197, 113-123.

Ibáñez, H., Ballester, A., muñoz, R. \& Quiles, M.J. (2010). Chlororespiration and tolerance to drought, heat and high illumination. Journal of Plant Physiology, 167, 732-738.

IPCC Fourth Assessment Report (2007). Climate Change 2007. United Nations Intergovernmental Panel on Climate Change (IPCC).

Jensen, C.R., Battilani, A., Plauborg, F., Psarras, G., Chartzoulakis, K., Janowiak, F., Stikic, R., Jovanovic, Z., Li, G., Qi, X., Liu, F., Jacobsen, S.E. \& Andersen, M.N. (2010). Deficit irrigation based on drought tolerance and root signaling in potatoes and tomatoes. Agricultural Water Management, 98, 403-413.

Jia, W.S. \& Zhang, J.H. (1999). Stomatal closure is induced rather by prevalling xylem abscisic acid than by accumulated amount of xylem-derrived abscisic acid. Physiologia Plantarum, 106, 268-275.

Jones, H.G, (1980). Interaction and integration of adaptive responses to water stress: the implication of an unpredictable environment. In: Adaptation of plants to water and high temperature stress. Turner, N.C., P.J. Kramer, Ed. Wiley, New York, 353-365. 
Kaiser, WM (1987). Effects of water deficit on photosynthetic capacity. Physiologia Plantarum, $71,142-149$.

Keck, R.W. \& Boyer, J.S. (1974). Chloroplast response to low leaf water potentials. III. Differing inhibition of electron transport and photophosphorylation. Plant Physiology, 53, 474-479.

Kim, J.Y., Mathé, A., Guy, S., Brangeon, J., Roche, O., Chourey, P.S., \& Prioul, J.L. (2000). Characterization of two members of the maize gene family. Ivr2 and Incw4, encoding cell-wall invertases. Gene, 245, 89-102.

Kirchbaum, M.U.F. (1987). Water stress in Eucalyptus pauciflora: comparison of effects on stomatal conductance with effects on the mesophyll capacity for photosynthesis, and investigation of a possible involvement of photoinhibition. Planta, 171, 466-473.

Kirda C, Topcu S, Kaman H, Ulger AC, Yazici A, Cetin M, \& Derici MR (2005). Grain yield response and $\mathrm{N}$-fertilizer recovery of maize under deficit irrigation. Field Crops Research, 93, 132-141.

Kirda, C., Cetin, M., Dasgan, Y., Topcu, S., Kaman, H., Ekici, B., Derici, M.R. \& Ozguven, A.I. (2004). Yield response of greenhouse grown tomato to partial root drying and conventional deficit irrigation. Agricultural Water Management, 69, 191-201.

Kiyosue T, Yoshiba Y, Yamaguchi-Shinozaki K, \& Shinozaki K. (1996). A nuclear gene encoding mitochondrial proline dehydrogenase, an enzyme involved in proline metabolism, is upregulated by proline but downregulated by dehydration in Arabidopsis. The Plant Cell 8, 1323-1335.

Kramer,P.J., \& Boyer, J.S. (1995). Water relations of plants and soils. New York: Academic Press, 1995, $495 \mathrm{p}$.

Krapp, A., Hofmann, B., Schàfer, C. \& Stitt, M. (1993). Regulation of the expresion of rbcS and other photosynthetic genes by carbohydrate: a mechanism for the "sink regulation" of photosynthesis? The Plant Journal, 3, 817-828.

Krieg, N.D. (1983). Photosynthetic activity during stress. Agricultural Water Management, 7, 249-263.

Krömer, S., Malmberg, G., \& Gardeström, P., (1993). Mitochondrial contribution to photosynthetic metabolism. A study with barley (Holdeum vulgare L.) leaf protoplasts at different light intensities and $\mathrm{CO}_{2}$ concentrations. Plant Physiology, 102, 947-955.

Krömer, S., Stitt, M., \& Heldt, H.W., (1988). Mitochondrial oxidative phosphorylation participating in photosynthetic metabolism of a leaf cell. FEBS Letters, 226, 352356.

Laing, J., Zhang, J., \& Wong, M.H., (1996). Effects of air-filled porosity and aeration on the initiation and growth of secondary roots of maize (Zea mays). Plant Soil, 186, 245-254.

Lawlor, D.W. \& Cornic, G. (2002). Photosynthetic carbon assimilation and associated metabolism in relation to water deficits in higher plants. Plant, Cell and Environment, 25, 275-294.

Li Z, Zhang F, \& Kang S (2005). Impacts of the controlled roots divided alternative irrigation on water and nutrient use of winter wheat. Trans CSAE, 21, 17-21. 
Li, L, \& Staden, JV (1998). Effects of plant growth regulators on the antioxidant system in callus of two maize cultivars subjected to water stress. Plant Growth regulation, 24, 55-66.

Liu F, Jensen CR, \& Andersen MN (2004) Drought stress effect on carbohydrate concentration in soybean leaves and pods during early reproductive development: its implication in altering pod set. Field Crop Research, 86, 1-13.

Louwerse, W. (1980). Effects of $\mathrm{CO}_{2}$ concentration and irradiance on the stomatal behavior of maize, barley, and sunflower plants in the field. Plant Cell Environment, 3, 391-398.

Loveys, B.R. (1991). What use is a knowledge of ABA physiology for crop improvement? In: Environment plant biology. Physiology and biochemistry of abscisic acid. Oxford: Bios Scientific Publishers, 245-250.

Loveys, B.R. Stoll, M., Dry, P.R. \& McCarthy, M.G. (2000). Using plant physiology to improve the water use efficiency of

Loveys, B.R. \& During, H. (1984). Diurnal changes in water relations and abscisic acid in field-grown Vitis vinifera cultivars. II. Abscisic acid changes under semi-arid conditions. New phytologist, 97, 37-47.

MacCabe, TC, Daley, D, \& Whelan, J (2000). Regulatory, developmental and tissue aspects of mitochondrial biogenesis in plants. Plant Biology, 2, 121-135.

Mackenzie, S. \& MacIntosh, L. (1999). Higher plant mitochondria. The Plant Cell, 11, 571-585.

Martim, SA, Santos, MP, Peçanha, AL, Pommer, C, Campostrini, E, Viana AP, Façanha, AR \& Bressan-Smith, R (2009). Photosynthesis and cell respiration modulated by water deficit in grapevine (Vitis vinifera L.) cv. Cabernet Sauvignon. Brazilian Journal of Plant Physiology, 21, 95-102.

Masle J (1999). Root impedance: sensing, signaling and physiological effects. In: Plant responses to environmental stresses from phytohormones to genome reorganization. HR Lerner (editor) pp.475-495, Marcel Dekker Inc. New York.

Maxwell, DP, Wang, Y \& McIntosh, L (1999). The alternative oxidase lowers mitochondrial reactive oxygen production in plant cell. Proceedings National Academy Science, 96, 8271-8276.

Medrano, H, Flexas, J \& Galmés, J (2009). Variability in water use efficiency at the leaf level among Mediterranean plants with different growth forms. Plant Soil, 317, 17-29.

Melgar, J.C., Dunlop, J.M. \& Syvertsen, J.P. (2010). Growth and physiological responses of the citrus rootstock Swingle citrumelo seedlings to partial rootzone drying and deficit irrigation. Journal of Agricultural Science, 148, 593-602.

Mingo, D.M., Theobald, J.C., Bacon, M.A., Davies, W.J., \& Dodd, I.C., (2004). Biomass allocation in tomato (Lycopersicon esculentum) plants grown under partial rootzone drying: enhancement of root growth. Functional Plant Biology, 31, 971978.

Moore, AL, \& Siedow, JN (1991). The regulation and nature of the cyanide resistant alternative oxidase of plant mitochondria. Biochimestry and Biophysical Acta, 1058, 121-140.

Munné-Bosch, S., Falara, V., Pateraki, I., López-Carbonell, M., Cela, J., \& Kanellis, A.K. (2009). Physiological and molecular responses of the isoprenoid biosynthetic pathway in a drought-resistent Mediterranean shrub, Cistus Crectus exposed to water deficit. Journal of Plant Physiology, 166, 136-145. 
Noctor, G, Dutilleul, C, De Paepe, R, \& Foyer, CH (2004). Use of mitochondrial electron transport mutants to evaluate the effects of redox state on photosynthesis, stress tolerance and the integration of carbon/nitrogen metabolism. Journal of Experimental Botany, 55, 49-57.

Nunes-Nesi, A., Sulpice, R., Gibon, Y. \& Fernier, A.R. (2008). The enigmatic contribution of mitochondrial function in photosynthesis, Journal of Experimental Botany, 59, 16751684.

Padsmareee, K \& Raghavendra, AS (1999.) Importance of oxidative electron transport over oxidative phosphorylation in optimizing photosynthesis in mesophyll protoplasts of pea (Pisum sativum L.). Physiologia Plantarum, 105, 546-553.

Passioura, J.B., (1988). Root signals control leaf expansion in wheat seedlings growing in drying soil. Australian Journal of Plant Physiology, 15, 687-693.

Pastore, D., Trono, D., Laus, M.N., Di Fonzo, N. \& Flagella, Z. (2007). Possible plant mitochondria involvement in cell adaptation to drought stress. A case study: durum wheat mitochondria. Journal of Experimental Botany, 58, 195-210.

Pelleschi, S., Guy, S., Kim, J.Y., Pointe, C., Mathé, A., Barthes, L., Leonardi, A., \& Prioul, J.L. (1999). Ivr2, a candidate gene for a QTL of vacuolar invertase activity in maize leaves. Gene-Specific expression under water stress. Plant Molceular Biology, 39, 373380.

Pelleschi, S., Rocher, P. \& Prioul, J.L. (1997). Effect of water restriction on carbohydrate metabolism and photosynthesis in mature maize leaves. Plant, Cell and Environment, 20, 493-503.

Pinheiro, C., Chaves, M.M. \& Ricardo, C.P. (2001). Alterations in carbon and nitrogen metabolism induced by water deficit in the stems and leaves of Lupins albus L. Journal of Experimental Botany, 52, 1063-1070.

Popov, VN, Simonian, RA, Skulachev, VP \& Starkov, AA (1997). Inhibition of the alternative oxidase stimulates $\mathrm{H}_{2} \mathrm{O}_{2}$ production in plant mitochondria. FEBS Letters, 416, 87-90.

Pou, A, Flexas, J, Alsina Mdel mar, Bota, J, Carambula, C, Herralde, F, Galmés, J, Lovisolo, C, Jimenez, M, Ribas-Carbo, M, Rusjan, D, Sechi, F, Tomàs, M, Zsófi, Z \& Medrano, $\mathrm{H}$ (2008). Adjustments of water use efficiency by stomatal regulation during drought and recovery in the drought-adapted Vitis hybrid Richter-110 (V. berlandieri x V. ruprestris). Physiologia Plantarum, 134, 313-323.

Quick, W.P., Chaves, M.M., Wendler, R., David, M.M., Rodrigues, M.L., Pereira, J.S., Leegood, R. \& Stitt, M. (1992). Effects of water stress on photosynthetic carbon metabolism in four species grown in Field conditions. Plant Cell and Environment, 15, 25-35.

Quick, W.P., Siegl, G., Neuhaus, E., Feil, R. \& Stitt, M. (1989). Short-term water stress leads to a stimulation of sucrose synthesis by activating sucrose phosphate synthase. Planta, 177, 535-547.

Radford, BJ, Yule, DF, McGarry, D \& Playford, C (2001). Crop responses to applied soil compaction and to compaction repair treatments. Soil $\mathcal{E}$ Tillage Research, 61, 157166.

Rhoads DM, Umbach AL, Subbaiah CC, \& Siedow JN. (2006). Mitochondrial reactive oxygen species: contribution to oxidative stress and interorganellar signaling. Plant Physiology, 141, 357-366. 
Roitsch, T., \& Gonza' lez, M.C. (2004). Function and regulation of plant invertases: sweet sensations. Trends Plant Science, 9, 606-613.

Roitsch, T., Büttner, M., \& Godt, D.E. (1995). Induction of apoplectic invertase of chenopodium rubrum by D-glucose and a glucose analog and tissue-specific expression suggest a role in sink-source regulation. Plant Physiology, 108, 285-294.

Rolland, F., Gonzales-Baena, E. \& Sheen, J. (2006). Sugar sensing and signaling in plants: conserved and novel mechanisms. Annual Review of Plant Biology, 57, 675-709.

Saini, H.S., \& Westgate, M.E. (2000).. Reproductive development in grain crops during drought. Advances in Agronomy. 68, 59-96.

Scandalios, JG (1993). Oxygen stress and superoxide dismutase. Plant Physiology, 101, 7-12.

Schonmaum, GR, Bonner, WD, Storey, BT, \& Bahr, JT (1971). Specific inhibition of the cyanide-insensitive respiratory pathway in plant mitochondria by hydroxamic acids. Plant Physiology, 47, 124-128.

Sergeeva, L.I., Keurentjes, J.J., Bentsink, L., Vonk, J., van der Plas, L.H., Koornneef, M., \& Vreugdenhil, D. (2006). Vacuolar invertase regulates elongation of Arabidopsis thaliana roots as revealed by QTL and mutant analysis. Proceedings of National Academy Science, 103, 2994-2999.

Shahnazari A, Ahmadi SH, Laerke PE, Liu F, Plauborg F, Jacobsen S-E, Jensen CR, \& Andersen MN (2008). Nitrogen dynamics in the soil-plant system under deficit and partial root-zone drying irrigation strategies in potatoes. European Journal of Agronomy, 28, 65-73.

Sheen, J. (1990). Metabolic repression of transcription in higher plants. The Plant Cell, 2, 10271038.

Siedow, JN \& Grivin, ME (1980). Alternative respiratory pathway. Its role in seed respiration and its inhibition by propyl galalate. Plant Physiology, 65, 669-674.

Smeekens, S \& Rook, F (1997). Sugar sensing and sugar-mediated signal transduction in plants. Plant Physiology, 115, 7-13.

Smeekens, S. (2000). Sugar-induced signal transduction in plants. Annual Review Plant Physiology and Plant Molecular Biology. 51, 49-81.

Steduto, P., Hsiao, T.C., \& Fereres, E., (2007). On the conservative behavior of biomass water productivity. Irrigation Scence, 25, 189-207.

Steduto, P., Hsiao, T.C., Raes, D., \& Fereres, E., (2009). AquaCrop - the FAO crop model to simulate yield response to water: I. Concepts and underlying principles. Agronomy Journal, 101: 426-437.

Stitt, M. \& Quick, W.P. (1989). Photosynthetic carbon partitioning: its regulation and possibilities for manipulation. Physiologia Plantarum, 77, 633-641.

Stoll, M., Loveys, B. \& Dry, P. (2000). Hormonal changes induced by partial rootzone drying of irrigated grapevine. Journal of Experimental Botany, 51, 1627-1634.

Sturm A (1996). Molecular characterization and functional analysis of sucrose-enzymes in carrot (Daucus carota L.). Journal of Experimental Botany, 47, 1187-1192.

Sturm, A. \& Tang, G.Q. (1999). The sucrose-cleaving enzymes of plants are crucial for development, growth and carbon partitioning. Trends in Plant Science, 4, 401-406.

Svensson, A.S., \& Rasmusson, A.G., (2001). Light-dependent gene expression for proteins in the respiratory chain of potato leaves. Plant Journal, 28, 73-82. 
Topcu S, Kirda C, Dasgan Y, Kaman H, Cetin M, Yazici A, \&Bacon MA (2007). Yield response and $\mathrm{N}$-fertiliser recovery of tomato grown under deficit irrigation. European Journal of Agronomy, 26, 64-70.

Treeb, M.T., Henriod, R.E., Bevington, K.B., Milne, D.J. \& Storey, R. (2007). Irrigation management and rootstock effects on navel orange (Citrus sinensis L. Osbeck) fruit quality. Agricultural Water Management, 91, 24-32.

Trouverie, J., Chateau-Joubert, S., Thévenot, C., Jacqemot, M.P., \& Prioul, J.L. (2004). Regulation of vacuolar invertase by abscisic acid or glucose in leaves and roots from maize plants. Planta, 219, 894-905.

Trouverie, J., Thévenot, C., Rocher, J.P., Sotta, B., \& Prioul, J.L. (2003). The role of abscisic acid in response of a specific vacuolar invertase to water stress in the adult maize leaf. Journal of Experimental Botany, 54, 2177-2186.

Tzara, W, Mittichell, VJ, driscoll, SD, \& Lawlor, DW (1999). Water stress inhibits plant photosynthesis by decreasing coupling factor and ATP. Nature, 401, 914917.

Umbach, AL, Fiorani, F \& Siedow, JN (2005). Characterization of transformed Arabidopsis with altered alternative oxidase levels and analysis of effects on reactive oxygen species in tissues. Plant Physiology, 139, 1806-1820.

Vanlerberghe, G.C., \& McIntosh, L. (1997). Alternative Oxidase: From gene to function. Annual Review of Plant Physiology and Plant Molecular Biology, 48, 703-734.

Vassey, T.L. \& Sharkey, T.D. (1989). Mild water stress of Phaseolus vulgaris plants leads to reduced starch synthesis and extractable sucrose phosphate synthase activity. Plant Physiology, 89, 1066-1070.

Wagner, AM, \& Krab, K (1995). The alternative respiration pathway in plants? Role and regulation. Physiologia Plantarum, 95, 318-325.

Wang, H., Liu, F., Andersen, M.N. \& Jensen, C.R. (2009). Comparative effects of partial rootzone drying and deficit irrigation on nitrogen uptake in potatoes (Solanum tuberisum L.). Irrigation Science, 27:443-448.

Wang, H., Liu, F., Andersen, M.N. \& Jensen, C.R. (2009). Comparative effects of partial rootzone drying and deficit irrigation on nitrogen uptake in potatoes (Solanum tuberosum L.). Irrigation Science, 27, 443-448.

Wang, Y., Liu, F., Nerrgaard, A., Jensen, L.S., Luxhoi, J. \& Jensen, C.R. (2010). Alternate partial root-zone irrigation induced dry/wet cycles of soils stimulate $\mathrm{N}$ mineralization and improve N nutrition in tomatoes. Plant soil, 337, 167-177.

WRI (2005). World Resources Institute: Freshwater resources.

Yang, J., Zhang, J., Wang, Z. \& Zhu, Q. (2001). Activities of starh hydrolitic enzymes and sucrose-phosphate synthase in the stems of rice subjected to water stress during grain filling. Journal of Experimental Botany, 52, 2169-2179.

Yoshida, K, Terashima, I \& Noguchi, K (2007). Up-regulation of mitochondrial alternative oxidase concomitant with chloroplast over-reduction by excess light. Plant Cell Physiology, 48, 606-614.

Yoshida, K., Terashima, I. \& Noguchi, K. (2006). Distinct roles of the cytochrome pathway and alternative oxidase leaf photosynthesis. Plant Cell Physiology, 47, 22-31.

Young IM, Montagu K, Conroy J, \& Bengough AG (1997). Mechanical impedance of root growth directly reduces leaf elongation rates of cereals. New Phytologist, 135, 613619. 
Zegbe, J.A., Benboudian, M.H., \& Clothier, B.E. (2006). Yield and fruit quality in processing tomato under partial rootzone drying. European Journal Horticultural Science, 71, 252-258.

Zinselmier, C., Westgate, M.E., Schussier, J.R. \& Jones, R. (1995). Low water potential disrupts carbohydrate metabolism in Maize (Zea mays L.) ovaries. Plant Physiology, 107, 385-391. 


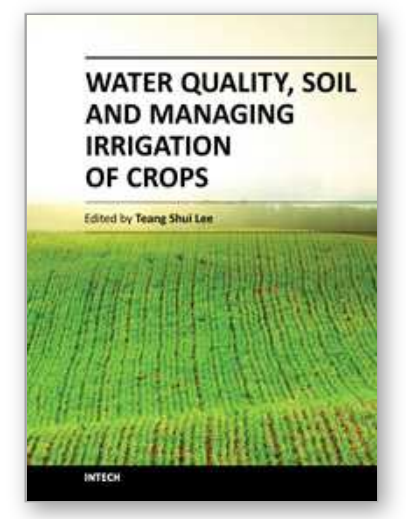

\author{
Water Quality, Soil and Managing Irrigation of Crops \\ Edited by Dr. Teang Shui Lee
}

ISBN 978-953-51-0426-1

Hard cover, 242 pages

Publisher InTech

Published online 28, March, 2012

Published in print edition March, 2012

The book entitled Water Quality, Soil and Managing Irrigation of Crops comprises three sections, specifically: Reuse Water Quality, Soil and Pollution which comprises five technical chapters, Managing Irrigation of Crops with four, and Examples of Irrigation Systems three technical chapters, all presented by the respective authors in their own fields of expertise. This text should be of interest to those who are interested in the safe reuse of water for irrigation purposes in terms of effluent quality and quality of urban drainage basins, as well as to those who are involved with research into the problems of soils in relation to pollution and health, infiltration and effects of irrigation and managing irrigation systems including basin type of irrigation, as well as the subsurface method of irrigation. The many examples are indeed a semblance of real world irrigation practices of general interest to practitioners, more so when the venues of these projects illustrated cover a fair range of climate environments.

\title{
How to reference
}

In order to correctly reference this scholarly work, feel free to copy and paste the following:

Silvia Aparecida Martim, Arnoldo Rocha Façanha and Ricardo Enrique Bressan-Smith (2012). Developing Crop-Specific Irrigation Management Strategies Considering Effects of Drought on Carbon Metabolism in Plants, Water Quality, Soil and Managing Irrigation of Crops, Dr. Teang Shui Lee (Ed.), ISBN: 978-953-510426-1, InTech, Available from: http://www.intechopen.com/books/water-quality-soil-and-managing-irrigationof-crops/developing-crop-specific-irrigation-management-strategies-considering-effects-of-drought-on-carbon$\mathrm{m}$

\section{INTECH}

open science | open minds

\section{InTech Europe}

University Campus STeP Ri

Slavka Krautzeka 83/A

51000 Rijeka, Croatia

Phone: +385 (51) 770447

Fax: +385 (51) 686166

www.intechopen.com

\section{InTech China}

Unit 405, Office Block, Hotel Equatorial Shanghai

No.65, Yan An Road (West), Shanghai, 200040, China 中国上海市延安西路65号上海国际贵都大饭店办公楼 405 单元

Phone: +86-21-62489820

Fax: $+86-21-62489821$ 
(C) 2012 The Author(s). Licensee IntechOpen. This is an open access article distributed under the terms of the Creative Commons Attribution 3.0 License, which permits unrestricted use, distribution, and reproduction in any medium, provided the original work is properly cited. 